\title{
ЗАЛУЧЕННЯ ПРЯМИХ ІНОЗЕМНИХ ІНВЕСТИЦІЙ В ЕКОНОМІКУ ІНДІї: ДОСВІД ДЛЯ УКРАЇНИ
}

\author{
Макарчук К.О., к.е.н., ст. викладач, \\ Шуба М.В., к.е.н., доцент (ХНУ імені В. Н. Каразіна)
}

У статті досліджено позииії Індї в міжнародних рейтингах, щุо стосуються інвестииійної привабливості; проаналізовано взаємозв'язок між надходженням прямих іноземних інвестицій та кредитними рейтингами Індії; визначено взаємозв'язок між ВВП і припливом прямих іноземних інвестицій в Індію; систематизовано причини привабливості Індії для іноземних інвесторів; узагальнено основні можливості застосування досвіду Індї для стимулювання залучення прямих іноземних інвестицій в Украӥну.

Ключові слова: прямі іноземні інвестицій, інвестиційний клімат, інвестор, економіка Індї, економічний розвиток, рейтинг.

\section{ПРИВЛЕЧЕНИЕ ПРЯМЫХ ИНОСТРАННЫХ ИНВЕСТИЦИЙ В ЭКОНОМИКУ ИНДИИ: ОПЫТ ДЛЯ УКРАИНЫ}

\author{
Макарчук Е.A., к.э.н., ст. преподаватель, \\ Шуба М.В., к.э.н., доцент (ХНУ имени В. Н. Каразина)
}

В статье исследованы позищии Индии в международных рейтингах, касающихся инвестиционной привлекательности; проанализирована взаимосвязь между притоком прямых иностранных инвестищий (ПИИ) и кредитными рейтингами Индии; определена взаимосвязь между ВВП и притоком прямых иностранных инвестииий в Индию; систематизированы факторы привлекательности Индии для иностранных инвесторов; обобщены основные возможности применения опыта Индии для стимулирования привлечения прямых иностранных инвестищий в Украину.

Ключевые слова: прямые иностранные инвестиции, инвестиционный климат, инвестор, экономика Индии, экономическое развитие, рейтинг.

\section{ATTRACTION OF FOREIGN DIRECT INVESTMENTS IN INDIA'S ECONOMY: EXPERIENCE FOR UKRAINE}

\author{
Makarchuk K., Ph.D. (Economics), Senior Lecturer, \\ Shuba M., Ph.D. (Economics), Associate Professor \\ (V. N. Karazin Kharkiv National University)
}

One of the priority tasks for many countries of the world is to increase the volume of foreign investment. In Ukraine the volume of direct foreign investments is insignificant and the dynamic of their attraction is rather slow. Therefore, the study of the experience of India, which is one of the leading countries in attracting foreign direct investment, is of scientific and practical interest. The subject of the article's research is the foreign direct investment in the Indian economy. The goal is to determine opportunities to apply the India's experience to stimulate foreign direct investment in Ukraine. The objective is to research the measures

(C) Макарчук К.O.,

Шуба М.В.

Вісник економіки транспорту і промисловості № 65, 2019 
taken by the Indian Government to increase the attractiveness of the country for foreign investors. Methods: system analysis is used to determine the key characteristics of the Indian Economic Reform Model; trend analysis - to predict the inflow of FDI to India; correlation analysis - to determine the correlation between GDP and inflow of foreign direct investment to India. The following results were obtained: India's position in international ratings related to investment attractiveness was researched; the connection between FDI inflow and India's credit ratings was analyzed; the correlation between GDP and inflow of foreign direct investment to India was determined; India's reasons for attracting foreign investors were systematized; general opportunities for using India's experience to stimulate the attraction of foreign direct investment to Ukraine were summarized. Conclusions: some aspects of Indian experience in attracting foreign direct investment can be used as recommendations to stimulate the attraction of foreign direct investment to Ukraine.

Key words: foreign direct investment, investment climate, investor, economy of India, economic development, rating.

Постановка проблеми. Одним 3 факторів впливу на ефективне формування економічних відносин у сучасній економіці є масштабні іноземні інвестиції, що забезпечують розвиток діючих виробництв i підприємств, покращують систему їх управління, впроваджують новітні технології i відновлюють такі розвинені інфраструктури, як виробнича, транспортна і ринкова.

Для багатьох держав світу, у тому числі, й для України, залучення іноземних інвестицій $\epsilon$ досить актуальною проблемою. В Україні обсяг прямих іноземних інвестицій (ПІІ) є незначним, а темпи їх залучення досить повільні. Тому, на наш погляд, доцільно дослідити досвід Індії, яка сьогодні є однією з країн-лідерів по залученню прямих іноземних інвестицій.

Аналіз останніх досліджень i публікацій. Аналіз останніх досліджень і публікацій показує, що тема є предметом уваги вчених. Так, Н. В. Галищева [1], В. Г. Кандалинцев [2] та К. Я. Ревіна [3] у своїх працях досліджували інвестиційний клімат Індії, напрями залучення ПІІ в індійську економіку, причини привабливості Індії для іноземних інвесторів. Памі Дуа та Реетіка Гарг [4] у дослідженні розглядають макроекономічні фактори, що лежать в основі потоків ПІІ в Індію. Причинно-наслідковий зв'язок між розвитком фінансового сектору, прямими іноземними інвестиціями та економічним зростанням в Індії досліджено у роботі Аггарвал Віпін Кумар та Найяр Рішика [5]. Дослідження Р. Венкатесан [6] присвячено ролі прямих іноземних інвестицій у розвитку Індії.

Виділення невирішених частин загальної проблеми. Враховуючи прагнення України покращити свій інвестиційний клімат, необхідним $є$ удосконалення організаційної та правової бази, що зможе цьому сприяти. На наш погляд, для підвищення конкурентоспроможності української економіки та привабливості країни для іноземних інвесторів доцільно використовувати іноземний досвід, у тому числі й Індіï, дослідженню якого вітчизняними авторами приділено недостатньо уваги.

Мета статті. Визначення можливостей застосування досвіду Індії для стимулювання залучення прямих іноземних інвестицій в Україну.

Виклад основного матеріалу дослідження. Сьогодні сучасна Індія $€$ країною-прикладом, що динамічно розвивається, має потужну промисловість i військово-цивільну інфраструктуру, значні трудові ресурси, різноманітну мінерально-сировинну базу, зростаючий науково-технічний потенціал i сектор послуг, який швидко розширюється, а 
саме він включає будівельні та інжинірингові послуги, інформаційні технології та комунікації, фінансовобанківські й страхові послуги, торгівлю, транспорт і туризм. На розвиток країни значно вплинув іноземний капітал.

Соціально-економічна система, що склалася у колоніальний період, характеризувалася багатоукладністю, поєднанням капіталістичних i докапіталістичних форм господарства. Іноземний (британський) капітал діяв на індійському ринку через експорт своїх товарів, створюючи серйозну перешкоду розвитку індійської промисловості. Об'єднуючись у спільні підприємства, іноземний капітал привласнював частину прибутку індійських підприємств і грав вирішальну роль в управлінні й контролі. Проте слід зазначити, що іноземний капітал створив важливу інфраструктурну частину ринкової економіки Індії, а саме: залізниці, порти, зв'язок, чайні плантації, товарне виробництво бавовни, джуту, кави, каучуку, прянощів, заохочуючи їх виробництво в сільських господарствах i сприяючи їх включенню в ринкову (експортну) економіку [3].

Великий бізнес Індії, у свою чергу, конкуруючи 3 іноземним капіталом, протистояв дрібному підприємництву i ремісничому виробництву i створював монопольне виробництво, головним чином у текстильній та легкій промисловості. Представники торговолихварських каст вкладали гроші в будівництво фабрик, закуповуючи іноземну техніку і витісняючи ремесло і дрібне підприємництво [3].

Перед Індією постало складне завдання, яке передбачало створення незалежної економіки, що включає індустріалізацію, зростання виробництва сільськогосподарської продукції, створення ефективної економічної структури і завоювання нових позицій в міжнародному поділі праці [1].

Економічний розвиток незалежної Індії включає два етапи, два великих періоди: перший з кінця 1940-х рр. до 1991 p. i другий - 31991 року i до теперішнього часу. Для кожного етапу характерна своя модель економічного розвитку країни і їі включення в світову економіку.

На першому етапі була офіційно прийнята концепція так званого суспільства соціалістичного зразка (social pattern society), під яким розумілася змішана економіка і імпортозаміщуюча модель структурної модернізації з опорою на вирішальну роль держави і державний сектор економіки (держкапіталізм).

Лібералізація економіки Індії почалася ще в 80-i pp. i значно прискорилася в 90-і рр. ХX ст. Офіційно перехід до нового етапу розвитку економки відбувся у 1991 р., коли було проголошено економічну реформу, що отримала назву «Нової індустріальної політики» [2]. Реформи стосувалися трансформації державного сектору та державного регулювання економіки у цілому. Вони проводилися послідовно, незважаючи на зміну декількох урядів, 3 активною участю міжнародних фінансових інститутів. Серед основних рис «Нової індустріальної політики» Індії були і послаблення існуючих обмежень для іноземних інвесторів і заохочення ПІІ в пріоритетні галузі і регіони, можливість створення підприємств зі 100\%- вим іноземним капіталом [2]. Держава переходить від прямого втручання в економіку до індикативного планування, стимулює приватних інвесторів у пріоритетних напрямках, розширює економічні права штатів i місцевого самоврядування.

Економічні реформи 1990-х pp. надали новий імпульс економічному розвитку Індії, що позитивно позначилося на темпах зростання економіки.

Однією 3 головних рис реформи $є$ поліпшення інвестиційного клімату у країні та створення інвестиційної привабливості для іноземних інвесторів. Інвестиційна привабливість країни $є$ 
системоутворюючою категорією в понятті інвестиційного клімату [2].

При аналізі інвестиційних процесів у країні слід дослідити піi ключові макроекономічні показники. Основні макроекономічні показники розвитку Індії систематизовано в таблиці 1.

Таблиия 1

Окремі макроекономічні показники Індї у 2011-2018рр.

\begin{tabular}{|c|c|c|c|c|c|c|c|}
\hline 2011 & 2012 & 2013 & 2014 & 2015 & 2016 & 2017 & 2018 \\
\hline \multicolumn{8}{|c|}{ Індія } \\
\hline \multicolumn{8}{|c|}{ Населення (млрд чол.) } \\
\hline 1189,173 & 1205,074 & 1220,8 & 1236,345 & 1309,053 & 1324,171 & 1339,180 & 1370,049 \\
\hline \multicolumn{8}{|c|}{ ВВП (млрд дол. США) } \\
\hline 1823,05 & 1827,64 & 1856,72 & 2035,39 & 2089,87 & 2263,79 & 2439,01 & 2848,23 \\
\hline \multicolumn{8}{|c|}{ ВНП на душу населення (дол. США) } \\
\hline 1442,86 & 1496,48 & 1481,43 & 1486,15 & 1609,7 & 1639,75 & 1751,85 & 1977,28 \\
\hline \multicolumn{8}{|c|}{ Рівень інфляції (\%) } \\
\hline 6,49 & 10 & 9,4 & 5,8 & 4,9 & 4,5 & 3,8 & 2,3 \\
\hline
\end{tabular}

Джерело: [7, 8].

Індія стала більш активно приймати участь у міжнародному поділі праці, глобалізації, регіоналізації та інтеграції. Відображенням всіх позитивних тенденцій в економіці стало збільшення ВВП Індії (таблиця 1).

У той же час, слід відзначити, що суттєво змінилась галузева структура економіки, а саме: зменшилась частка сільського господарства у ВВП - $336,1 \%$ в 1981 р. до 14,8\% у 2018p., збільшилась частка промисловості - 25,9\% до $31,0 \%$, та сфери послуг - $338,0 \%$ до $54,2 \%$ відповідно [7,8].

Також поступово збільшується ВНП на душу населення. Як відомо, на інвестиційну привабливість країни впливає і рівень інфляції - чим нижче іiі рівень, тим вище привабливість країни для іноземних інвесторів. У 2011 р. інфляція у Індії склала $6,49 \%$, а у 2018 р. - 2,3\%. У цілому рівень інфляції загалом прийнятний i розглядається іноземними інвесторами як допустимий [9].

Таким чином, Індія стала розглядатися діловим суспільством як одна 3 перспективних країн для вигідного вкладання капіталу.

Також Індія викликає підвищений інтерес завдяки унікальній ефективній моделі реформування своєї економіки. На наш погляд до ключових характеристик цієї моделі можна віднести:

- лібералізацію ринку, надання пільг для розвитку підприємництва, орієнтація на внутрішній ринок;

- дешеву робочу силу, а також досить кваліфіковану, тому що англійська мова в Індії поширена серед населення, а більшість молоді, чи іiі батьки в змозі оплатити навчання, навчаються в американських i британських університетах;

- згідно 3 доповіддю ЮНКТАД щодо світових інвестицій за 2018 рік, Індія посіла 11 місце за обсягом прямих іноземних інвестицій, що склало 40 млрд дол. США [10];

- орієнтир на розвиток внутрішнього ринку, але в той же час основним напрямом є збільшення експорту в сфері послуг, який складає близько 54,2\% ВВП країни, забезпечуючи значний приплив іноземних інвестицій i зайнятість населення. Головними партнерами Індії в торгівлі послугами є розвинені країни, а саме: США, Канада, країни СС, Японія;

- слабка залежність від світових цін на нафту, а також зниження витрат на імпорт нафти i золота через їх низьку вартість [11].

У політиці залучення інвестицій у країну особливе значення має аналіз 
способів поліпшення інвестиційного клімату країни. Задля виявлення факторів інвестиційної привабливості економіки Індії проаналізуємо 3 рейтинги: індекс глобальної конкурентоспроможності, Doing Business, рейтинг країн світу за економічною свободою.

Згідно 3 останньою доповіддю Всесвітнього економічного форуму, за індексом

глобальної конкурентоспроможності країн світу Індія покращила свої показники порівняно 3 попередніми роками - індекс у 2017-2018 p. склав 4,6 пункти. Однак країна опинилася на одну позицію нижче, ніж у попередньому рейтингу, зайняв 40 місце, що, тим не менш, є кращим результатом, ніж у період з 2011-2016 роки (таблиця 2).

Таблиия 2

Індія у рейтингу глобальної конкурентоспроможності, 2011-2018рр.

\begin{tabular}{|c|c|c|}
\hline Роки & Рейтинг & Оцінка \\
\hline $2011-2012 \mathrm{pp}$. & 56 & 4,3 \\
\hline $2012-2013 \mathrm{pp}$. & 59 & 4,32 \\
\hline $2013-2014 \mathrm{pp}$. & 60 & 4,28 \\
\hline $2014-2015 \mathrm{pp}$. & 71 & 4,2 \\
\hline $2015-2016 \mathrm{pp}$. & 55 & 4,31 \\
\hline $2016-2017 \mathrm{pp}$. & 39 & 4,52 \\
\hline $2017-2018 \mathrm{pp}$. & 40 & 4,6 \\
\hline
\end{tabular}

Джерело: [12,13]

Сильними сторонами економіки Індії згідно рейтингу $\epsilon$ висока конкурентоспроможність компаній, ефективність ринку, інноваційний потенціал. Завдяки вдосконаленій грошово-кредитній та фіскальній політиці, індійська економіка стабілізувалася і нині може похвалитися найвищим зростанням серед країн Великої двадцятки. Пріоритетними напрямами реформування стали вдосконалення державних установ, відкриття економіки іноземним інвесторам та міжнародної торгівлі, і підвищенні прозорості в фінансовій системі

За даними рейтингу Doing Business 2019 Індія значно покращила свій результат, піднявшись 3 100-го місця у рейтингу за 2018 рік на 77 місце [14].

Згідно 3 даними рейтингу Doing Business, Індія є однією з небагатьох країн, яким вдалося у більшій мірі поліпшити економічну ситуацію. Таких результатів Індія змогла домогтися завдяки реформам, які проводяться урядом прем'єр-міністра Наренда Моді, який у 2018 році посів 9 місце у рейтингу найвпливовіших людей світу за версією журналу Forbes.

Ситуація 3 деякими проблемними сферами не змінюється. Так, аналіз вищезазначених субіндексів дозволяє зазначити, що для подальшого конкурентоспроможного розвитку Індії урядом проведено цілий пакет заходів: у електроенергетиці - зробивши електроенергію швидше i дешевше шляхом упорядкування процесу отримання нового комерційного електричного з'єднання; у оподаткуванні введено електронну систему оплати податків; у міжнародній торгівлі Індія запустила ICEGATE - це портал, який надає послуги електронного подання торговцям та перевізникам та іншим клієнтам митного департаменту для спрощення експорту та імпорту товарів та послуг [14].

Останній 3 досліджуваних рейтингів - рейтинг за індексом економічної свободи. Індія у даному рейтингу віднесена до категорії країн 3 переважно невільною економікою - 129 місце у 2019 році серед 186 країн. Хоча позиція Індії у 
рейтингу невисока, країна поступово іiі покращує, що зумовлено покращенням ефективності суддів, ділової свободи, цілісності уряду та фіскальної свободи [15].

Для Індії, як для країни 3 емерджентною економікою, надзвичайно важливими $є$ також кредитні рейтинги. Сприятливий рейтинг дозволяє урядам та компаніям залучати капітал на міжнародному фінансовому ринку [16].

У таблиці 3 наведено динаміку кредитного рейтингу Індії та приток ПІІ до країни. Рейтингова оцінка Індії згідно $з$ рейтингом Moody`s змінилася зі спекулятивного рівня на інвестиційний у 2004 році, а за рейтингами S\&P та Fitch у 2006 році, та більше не знижувалась, відбувалась лише зміна в прогнозах напрямку. Варто відзначити, що після глобальної світової кризи у 2008 році у багатьох країн світу рейтинг був знижений, але Індія залишилась 3 рейтингом інвестиційного рівня.

Таблиия 3

Динаміка кредитного рейтингу Індії та залучення прямих іноземних інвестицій, 2000-2018 pik

\begin{tabular}{|l|c|c|c|c|}
\hline Рік & $\begin{array}{c}\text { Прямі іноземні } \\
\text { інвестиції, млрд дол. США }\end{array}$ & S\&P & Moody`s & Fitch \\
\hline 2000 & 3,584 & BB & Ba2 & BB+ \\
\hline 2001 & 1,771 & BB & Ba2 & BB \\
\hline 2002 & 1,583 & BB & Ba2 & BB \\
\hline 2003 & 3,322 & BB & Ba1 & BB \\
\hline 2004 & 5,429 & BB & Baa3 & BB+ \\
\hline 2005 & 7,269 & BB & Baa3 & BB+ \\
\hline 2006 & 20,029 & BBB & Baa3 & BBB- \\
\hline 2007 & 25,228 & BBB- & Baa3 & BBB- \\
\hline 2008 & 43,406 & BBB- & Baa3 & BBB- \\
\hline 2009 & 35,581 & BBB- & Baa3 & BBB- \\
\hline 2010 & 27,397 & BBB- & Baa3 & BBB- \\
\hline 2011 & 36,499 & BBB- & Baa3 & BBB- \\
\hline 2012 & 23,996 & BBB- & Baa3 & BBB- \\
\hline 2013 & 28,153 & BBB- & Baa3 & BBB- \\
\hline 2014 & 34,577 & BBB- & Baa3 & BBB- \\
\hline 2015 & 44,009 & BBB- & Baa3 & BBB- \\
\hline 2016 & 44,459 & BBB- & Baa2 & BBB- \\
\hline 2017 & 39,996 & BBB- & Baa2 & BBB- \\
\hline 2018 & н/д & & & \\
\hline & & & & \\
\hline
\end{tabular}

Аналіз даних таблиці 3 та рисунку 1 свідчить про те, що до підвищення рейтингу зі спекулятивного до інвестиційного рівня, темпи зростання ПІІ були повільними. 3 цього часу обсяг притоку ПІІ у країну не був нижче рівня 2006 р. Результати тренд-аналізу свідчать, що у середньостроковій перспективі обсяг ПII може збільшитися.

Для визначення взаємозв'язку між ВВП і припливом прямих іноземних інвестицій в Індію нами були виконані розрахунки парної кореляції (табл. 4). 


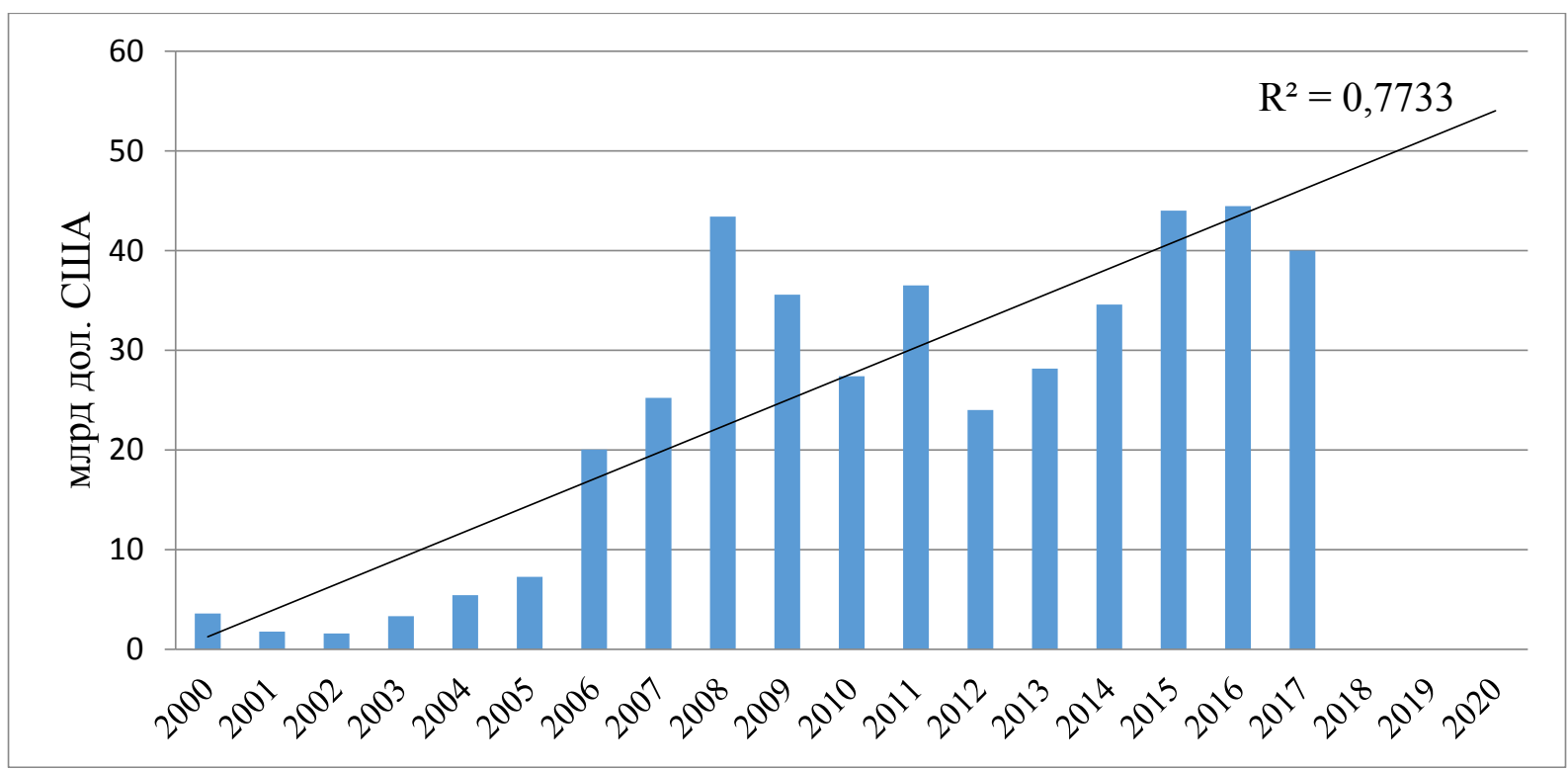

Рисунок 1. Динаміка притоку ПІІ в Індію у 2000-2017 рр., млрд дол. США [20]

Кореляціийний зв'язок між ВВП та ПІІ Індії

Таблиия 4

\begin{tabular}{|l|l|l|l|l|l|l|l|l|}
\hline & 2011 & 2012 & 2013 & 2014 & 2015 & 2016 & 2017 & $\mathrm{R}$ \\
\hline ВВП, млрд. дол. США & 1823,05 & 1827,64 & 1856,72 & 2035,39 & 2089,87 & 2263,79 & 2439,01 & \multirow{2}{*}{0,706} \\
\hline ПІІ, млрд. дол. США & 36,49 & 23,99 & 28,15 & 34,57 & 44,01 & 44,46 & 39,99 & \\
\hline
\end{tabular}

Результат розрахунку показав, що коефіцієнт кореляції (R) дорівнює 0,706 , що означає, що досліджувані показники демонструють достатньо високий рівень взаємозв'язку.
У таблиці 5 представлено провідні країни-інвестори в індійську економіку у період за 2000-2017 роки.

Таблиия 5

Провідні краӥни-інвестори в індійську економіку, 2000-2017 рр., млн дол. США

\begin{tabular}{|l|l|l|l|l|l|l|}
\hline Країни-інвестори & $2000-2012$ & 2013 & 2014 & 2015 & 2016 & 2017 \\
\hline Маврикій & 71808,95 & 5722,39 & 7073,12 & 9242,8 & 15069,46 & 16256,73 \\
\hline Сінгапур & 18792,56 & 3874,14 & 7092,38 & 13414,32 & 9822,18 & 10808,82 \\
\hline Японія & 14019,20 & 1420,73 & 2335,02 & 1739,42 & 5781,17 & 1722,89 \\
\hline Нідерланди & 8468,13 & 2112,94 & 3253,58 & 3003,32 & 2996,17 & 3250,52 \\
\hline США & 1111,90 & 771,9 & 1663,45 & 3855,07 & 2621,22 & 2183,16 \\
\hline Велика Британія & 17103,65 & 3606,48 & 1096,32 & 920,45 & 1660,86 & 936,74 \\
\hline Німеччина & 5133,46 & 1014,86 & 1151,57 & 1144,47 & 1102,76 & 1173,69 \\
\hline ОАЕ & 2362,04 & 283,94 & 279,28 & 521,88 & 1196,82 & 689,02 \\
\hline Швейцарія & 2316,32 & 282,19 & 367,89 & 270,54 & 433,46 & 509,25 \\
\hline Франція & 3407,21 & 441,37 & 612,07 & 428,77 & 650,19 & 651,74 \\
\hline
\end{tabular}

Джерело: [21]

У першу п'ятірку країн-інвесторів Індії з Маврикієм має давні традиції, тому входять Маврикій - 16256,73 млн дол., що 70\% населення Маврикії - вихідці 3 Сінгапур - 10808,82 млн дол., Нідерланди Індії. Інвестиційне співробітництво між -3250,52 млн дол., США - 2183,16 млн цими країнами почалося ще в 1983 році $з$ дол., Японія - 1722,89 млн дол.. Зв'язок 
моменту підписання угоди про вкладень в сектор послуг, як фінансових, виключення двостороннього податку [7]. так і не фінансових (таблиця 6).

Галузева структура розподілу ПІІ в

Індії характеризується переважанням

Таблиия 6

Приплив прямих іноземних інвестищій в Індію по галузям у $2000-2017$ рр., млн дол. США

\begin{tabular}{|l|l|l|l|l|l|l|}
\hline Країни-інвестори & $2000-2012$ & 2013 & 2014 & 2015 & 2016 & 2017 \\
\hline Маврикій & 71808,95 & 5722,39 & 7073,12 & 9242,8 & 15069,46 & 16256,73 \\
\hline Сінгапур & 18792,56 & 3874,14 & 7092,38 & 13414,32 & 9822,18 & 10808,82 \\
\hline Японія & 14019,20 & 1420,73 & 2335,02 & 1739,42 & 5781,17 & 1722,89 \\
\hline Нідерланди & 8468,13 & 2112,94 & 3253,58 & 3003,32 & 2996,17 & 3250,52 \\
\hline США & 1111,90 & 771,9 & 1663,45 & 3855,07 & 2621,22 & 2183,16 \\
\hline Велика Британія & 17103,65 & 3606,48 & 1096,32 & 920,45 & 1660,86 & 936,74 \\
\hline Німеччина & 5133,46 & 1014,86 & 1151,57 & 1144,47 & 1102,76 & 1173,69 \\
\hline ОАЕ & 2362,04 & 283,94 & 279,28 & 521,88 & 1196,82 & 689,02 \\
\hline Швейцарія & 2316,32 & 282,19 & 367,89 & 270,54 & 433,46 & 509,25 \\
\hline Франція & 3407,21 & 441,37 & 612,07 & 428,77 & 650,19 & 651,74 \\
\hline
\end{tabular}

Джерело: [21]

В останні півтора десятиліття Індія стала активно залучати ПII у високотехнологічні сектори: виробництво комп'ютерів і програмного забезпечення, нано- та біотехнології. Заохочення притоку іноземних інвестицій здійснюється також в галузі, які в сучасних умовах вимагають прискореного розвитку i швидкого технологічного оновлення: транспорт, телекомунікації, енергетику та ін. Інвестиції в інфраструктуру на стійкій основі - одна з серйозних проблем сучасної індійської економіки, яку намагаються вирішити, в тому числі, i за рахунок іноземного капіталу [11].

3 точки зору регіонального розміщення ПІІ в Індію, слід зазначити переважну орієнтацію іноземних інвесторів на найбільш економічно значущі міста Індії. Саме тут $\epsilon$ найбільш розвинена i розгалужена інфраструктура, що дозволяє 3 найменшими витратами імпортувати сировину та інші компоненти виробництва і експортувати готову продукцію. У цих містах також зосереджена основна маса великих i середніх промислових підприємств Індії, $\epsilon$ кваліфіковані інженерно-технічні кадри і дешева робоча сила.
Транснаціональні

корпорації, виходячи на ринок Індії, прагнуть отримати прибуток за рахунок зростання продуктивності в таких областях економіки, як IT та аутсорсинг бізнеспроцесів. Основними центрами, які надають такі послуги, є Бангалор, Мумбаї і Делі [3].

Транснаціональні корпорації відіграли важливу роль у розвитку Індії, які вкладали свій капітал для налагодження виробництва на місцевих територіях. Досягненню розвитку Індії сприяли сформована кон'юнктура ринків розвинутих країн, перенасичена інвестиціями, i вигідне географічне, транспортне положення країни, стабільність й автократичний характер їхніх політичних режимів, високий ступінь гарантій безпеки іноземних інвестицій. Певну роль відіграли й позаекономічні фактори: працьовитість, схильність до накопичення, дисциплінованість населення азіатських країн, його прагнення до покращення рівня життя.

У залученні іноземного капіталу в Індію використовувалась практика створення зон експортного виробництва взуття, одягу, текстильних виробів, 
електронних й електротехнічних товарів,напівфабрикатів, деталей i вузлів для автомобільної, машинобудівної й інших галузей промисловості [3].

Незважаючи на політичну нестабільність, недоліки інфраструктури і бюрократичні перешкоди, Індія $\epsilon$ перспективним майданчиком для зарубіжних інвестицій і робить необхідні кроки для того, щоб залучити більше іноземних інвесторів.

3 приходом до влади уряду Н. Моді, що підтримує глобалізацію економіки, активно реалізується цілий комплекс заходів i програм, спрямованих на стимулювання економічного розвитку країни. Дані заходи, в тому числі, стосуються вдосконалення державного управління та національного законодавства, поліпшення ділового та інвестиційного клімату в країні.

Запущені програми «Make in India» (розвиток виробничого потенціалу країни) i «Старт-ап Індія» (розвиток інновацій), «Стенд-ап Індія» (розвиток підприємництва), програми модернізації індійських залізниць i будівництва високошвидкісних магістралей, створення 100 «розумних міст », очищення річок i розвитку внутрішніх водних шляхів, програма «Доступне житло для всіх», пакет ініціатив «Цифрова Індія», програми розвитку металургії, електроенергетики та інші [11].

Запущена у 2014 р. програма Make in India $\epsilon$ великою національною програмою уряду Індіï, спрямованою на сприяння інвестиціям, стимулювання інновацій, підвищення кваліфікації, захисту інтелектуальної власності та створення найкращої в країні виробничої інфраструктури. Основною метою цієї ініціативи $є$ залучення інвестицій з усього світу та зміцнення виробничого сектора Індії. Програма дуже важлива для економічного зростання Індії, оскільки вона спрямована на використання існуючої індійської бази талантів, створення додаткових можливостей працевлаштування та розширення можливостей вторинного та третинного секторів. Програма також має на меті поліпшення рейтингу Індії за індексом легкості ведення бізнесу, усуваючи непотрібні закони та правила, полегшуючи бюрократичні процеси, роблячи уряд більш прозорим та відповідальним.

Програма Make in India зосереджена на 25 секторах. До них відносяться: хімічна промисловість, IT, фармацевтична промисловість, будівництво, оборонне виробництво, харчова промисловість, текстиль та одяг, туризм, поновлювані джерела енергії, біотехнології, теплова енергетика тощо [22].

Також Уряд Індії вживає різні заходи для забезпечення іноземним інвесторам сприятливих умов ведення бізнесу, проводить політику по залученню в країну іноземних інвестицій і технологій. Основні документи, що регулюють іноземну інвестиційну діяльність в Індії - це «Закон про валютне регулювання» від 1999 р. (Foreign Exchange Management Act, FEMA) та «Консолідована політика відносно прямих іноземних інвестицій» (Consolidated Foreign Direct Investment Policy (FDI Policy) [23].

Залежно від сфери економіки уряд країни законодавчо встановлює граничний рівень i умови допуску іноземних інвестицій (автоматичний режим або необхідність проходження процедури схвалення відповідними держорганами).

Сьогодні ПІІ дозволені у більшість галузей індійської економіки, обмеження у вигляді максимально допустимого порогу щодо участі іноземного капіталу зберігаються в деяких вразливих для країни сферах, зокрема, оборонній промисловості (49\%), теле - і радіомовленні (від 26\% до 49\%), роздрібній торгівлі (51\%), регулярних авіаперевезеннях (49\%), сільському господарстві, страхуванні і банківській діяльності (від 20\% до 74\%) [7].

Урядовим відомством, що регулює залучення ПІІ в індійську економіку $\epsilon$ Департамент промислової політики та 
розвитку Міністерства торгівлі і промисловості Індії, в функції якого входить розробка національної політики щодо прямих іноземних інвестицій. Департамент надає безпосереднє сприяння у вирішенні проблем іноземних інвесторів.

Уряд Індії послідовно проводить політику лібералізації економіки країни, усуває обмеження в області інвестування, спрощує бюрократичні процедури, підвищує прозорість в роботі державних органів влади, полегшує доступ іноземних технологій і інвестицій, заохочує державноприватне партнерство.

Серед прийнятих останнім часом заходів в частині лібералізації правового регулювання ПІІ в Індії можна відмітити зміни в законодавстві відносно ПІІ в області електронної роздрібної торгівлі, оборонної промисловості, будівництва, пенсійного сектора, цивільних авіаперевезень, виробництва медичних пристроїв [7].

Уряд Індії розробляє і впроваджує спеціальні інструменти, покликані підвищити привабливість Індії як «майданчика» для прямих іноземних інвестицій, для розміщення різних виробництв, орієнтованих на експорт. Одним 3 таких інструментів в країні $\epsilon$ спеціальні економічні зони (BE3).
Розвиток ВЕ3 в Індії почався 3 середини 1960-х років, це була перша подібна зона в Індії (і в Азії) яка була створена в 1965 р. в м. Кандла (шт. Гуджарат). На початковому етапі розвитку засновником ВЕЗ був виключно уряд країни [7]. Відповідно до чинних законів ВE3 можуть створюватися як центральним урядом, так і урядами штатів, а також 3 ініціативи представників бізнесу. На їх території можуть бути створені державні, приватні та приватно-державні підприємства. Дозволено 100\% участь іноземного капіталу в режимі «автоматичне схвалення» (не потрібно схвалення індійської влади). Найбільша кількість ВЕ3 за даними на 2017 р. розташовані в штатах Телангана (64), Карнатака (62), Махараштра (57), Таміл-Наду (50), АндхраПрадеш (29), Керала (29 ), Гуджарат (28) [7].

Незважаючи на успіх Індії у сфері залучення ПІІ, країні ще необхідно докласти чимало зусиль для подальшого покращення інвестиційної привабливості країни. Відповідно до проведеного компанією Ernst \& Young опитування, найбільш важливими для поліпшення інвестиційного клімату в Індії, на думку респондентів, є 13 напрямків (табл. 7) [24].

Таблиия 7

Напрями поліпшення інвестиційного клімату в Індії

\begin{tabular}{|l|c|}
\hline \multicolumn{1}{|c|}{ Напрями } & $\%$ \\
\hline Розвиток інфраструктури & 66 \\
\hline Підвищення ефективності правопорядку & 42,0 \\
\hline Зниження бюрократії & 31,8 \\
\hline Підвищення прозорості регулювання підприємницької діяльності & 44 \\
\hline Підвищення послідовності регуляторної політики & 11,0 \\
\hline Зниження юридичних та фінансових зобов'язань компаній & 8,7 \\
\hline Полегшення придбання землі та ліцензування & 9,9 \\
\hline Поліпшення трудового законодавства & 12,2 \\
\hline Удосконалення трудових навичок & 11,6 \\
\hline Полегшення доступу до капіталу & 8,0 \\
\hline Поліпшення системи оподаткування & 44 \\
\hline Зниження рівнів для ПІІ & 23 \\
\hline Стимулювання НДДКР і інновацій & 9,7 \\
\hline
\end{tabular}
Джерело: [24] 
Поліпшення інвестиційного клімату за даними напрямками має на увазі рішення великого комплексу проблем. Наприклад, в області розвитку інфраструктури уряд ініціював кілька великих проектів, таких як створення вантажного залізничного коридору в Мумбаї, швидкісної автомагістралі в Делі і проект поліпшення дорожнього покриття в Ченнаї. $\mathrm{У}$ майбутньому розвиток інфраструктури буде фокусуватися на завданнях оптимізації витрат і підвищення енергоефективності. У сфері підвищення ефективності правопорядку актуальна задача зниження рівня корупції [2].

Існує декілька причин, чому Індія $\epsilon$ привабливим та перспективним місцем для інвесторів:

1. Розмір ринку Індії. ВВП Індії нині складає 2,4 трильйона доларів США, що робить іï економіку 8-ою за величиною у світі. Проте, за паритетом купівельної спроможності ВВП Індії теоретично зростає в три рази (3,8 трлн. доларів США), що ставить їі на одне місце з Японією.

2. Економічне зростання. Економіка Індії, як очікується, збільшуватиметься на 9$10 \%$ в рік упродовж подальших 10 років. ВВП Індії виросте в п'ять разів в найближчі 20 років, а ВВП на душу населення майже в чотири рази.

3. Різноманіття. Індійська економіка пропонує інвесторам отримання широкого спектру можливостей: від споживчих товарів і фармацевтики до інфраструктури, енергетики і сільського господарства.

4. Демографічні показники. Індія $\epsilon$ однією з наймолодших за віком населення країн у світі, з середнім віком жителів 25 років. Очікується, що у 2020 році країна буде мати найбільшу кількість молодого населення у світі та стане найбільшим постачальником випускників університетів у світі. До 2025 року п'ята частина населення працездатного віку в світі буде індійською [25].

5. Високі накопичення заощаджень. 3 економічною ефективністю, що становить 37\% ВВП, індійські внутрішні заощадження підтримують велику частину своїх потреб в інвестиціях, і тільки 20\% загального державного боргу Індії поступає від зовнішніх позик.

6. Внутрішня економіка. Внутрішнє споживання в Індії, як правило, на чолі 3 приватним сектором, відіграє важливу роль в розвитку Індії i, як очікується, залишиться незмінним, оскільки все більше людей притягуються до трудової діяльності із зростаючого середнього класу. У найближчі 10 років кількість індійських багатих споживачів збільшиться на 40 млн. чоловік. Кожен сектор споживчого ринку в Індії знаходиться на підйомі, що робить Індію набагато менш уразливою до зовнішніх потрясінь і тисків, в порівнянні $з$ іншими ринками, що розвиваються.

7. Надійний фінансовий сектор. Індія має надійну, різноманітну i добре регульовану фінансову систему, яка дозволила їй пережити світову фінансову кризу без особливих труднощів, а також $\epsilon$ зразком якості, стійкості і прозорості. Індія має розвинутий банківський сектор, із звітами високої якості про фінансове положення, високим рівнем конкуренції (у Індії налічується більше 80 банків) і сильним корпоративним управлінням.

8. Якість інвестиційних ринків. Бомбейська фондова біржа $\epsilon$ другою найстарішою у світі (165 років) і пропонує інвесторам мало витратні, високоефективні, передові і добре регульовані умови, в яких досягають успіху в результаті незвичайного економічного зростання Індії.

9. Зростання економічного впливу. На думку експертів, центр глобальної морської торгівлі переміститься 3 Тихого океану до регіону Індійського океану. До 2030 року Індія i Китай будуть найбільшими виробничими центрами світу. Зв'язок 3 Центральною Азією та Європою через Міжнародний транспортний коридор Північ-Південь (INSTC). У наступні п'ять років Індія матиме більший економічний вплив на Азіатсько-Тихоокеанський регіон [21]. 
Висновки. Прямі іноземні інвестиції $\epsilon$ одним 3 основних джерел для економічного розвитку Індії. Іноземні компанії інвестують в індійську економіку для того, щоб скористатися відносно низькою заробітною платою працівників, спеціальними інвестиційними пільгами (наприклад, звільнення від податків) тощо. Сприятливий політичний режим індійського уряду та надійне бізнес-середовище забезпечили надходження іноземного капіталу в країну. В останні роки уряд України багато зробив у напрямку покращення iii інвестиційного клімату. Однак, на наш погляд, варто використати деякі аспекти досвіду Індії для стимулювання залучення ПІІ в Україну. Найбільш цікавим, на нашу думку, $\epsilon$ створення програми на кшталт Make in India.

\section{ПЕРЕЛІК ВИКОРИСТАНИХ ДЖЕРЕЛ}

1. Галищева Н. В. Чем Индия привлекает иностранных инвесторов / Н. В. Галищева // Азия и Африка сегодня. - 2012. - №1 - C. 29-35.

2. Кандалинцев В. Г. Индия: инвестиционный климат и приток ПИИ [Електронний ресурс]: Режим доступу: https://cyberleninka.ru/article/n/indiyainvestitsionnyy-klimat-i-pritok-pii

3. Ревина Е. Я. Прямые иностранные инвестиции в экономике Индии / Е.Я. Ревина // Вестник Московского Университета. - 2009. - № 3. - 39-47.

4. Pami Dua, Reetika Garg. Macroeconomic Determinants of Foreign Direct Investment: Evidence from India / Dua Pami, Garg, Reetika // The Journal of Developing Areas, 2015. - vol. 49(1). - pp. 133-155. Project

MUSE, doi:10.1353/jda.2015.0025. - Title from the screen.

5. Aggarwal Vipin Kumar, Nayyar Rishika. Financial sector development, Foreing direct investment and economic growth in India: an empirical analysis / Aggarwal Vipin Kumar, Nayyar Rishika // Asian Journal of
Research in Banking and Finance, 2017. - vol. 7. - Issue 6. - pp. 179-196. Режим доступу: http://www.indianjournals.co $\mathrm{m} /$ ijor.aspx?target=ijor:ajrbf $\&$ volume $=7$ \&issue $=6 \&$ article $=014$. - Title from the screen.

6. Venkatesan R. Role of Foreign Direct Investment in India / R.Venkatesan // International Journal of Advanced Scientific Research \& Development (IJASRD), 2018. Vol. 05. - Issue 03. - pp. 411 - 415. Режим доступу: https://www.ijasrd.org/wpcontent/uploads/2018/10/Role-of-Foreign-

Direct-Investment-in-India.pdf. - Title from the screen.

7. Department of Industrial Policy \& Promotion [Electronic resource]. - Mode of access : https://dipp.gov.in/foreign-directinvestment/foreign-direct-investment-policy. Title from the screen.

Режим

8. CEIC Data [Електронний ресурс]: https://www.ceicdata.com/en/indicator/india/gd p-per-capita. - Назва з екрана.

9. Index Mundi [Електронний ресурс] Режим доступу: https://www.indexmundi.com/g/g.aspx?c=in. Назва з екрана.

10. Доклади о мирових инвестициях [Электронный ресурс]: Конференция ЮНКТАД. Режим доступа: https://unctad.org/en/Pages/publications.aspx. Назва $з$ екрана.

11. Галищева Н.В. Глобализация индийской экономики: тенденции и перспективы / Н.В. Галищева // Вестник МГИМО-Университета. - 2017. - 2(53). C.71-89.

12. World Economic Forum [Electronic resource]. - Mode of access: https://www.weforum.org/search?query=Globa 1+Competitiveness+Report . - Title from the screen.

13. The Global Competitiveness Report 2017-2018 [Електронний ресурс]: Режим доступу: htps://espas.secure.europarl. europa.eu/orbis/sites/default/files/generated/doc ument/en/TheGlobalCompetitivenessReport20 17-2018.pdf. - Title from the screen. 
14. Doing Business: оценка качества и эффективности регулирования [Электронный ресурс] : Режим доступа : http://russian.doingbusiness.org/ru/reports/glob al-reports/doing-business-2019. - Назва 3 екрана.

15. Index of Economic Freedom [Electronic resource]. - Mode of access: http://www.heritage.org/index/country/India. Title from the screen.

16. The Conversation. Why credit rating agencies matter for developing countries [Electronic resource]. - Mode of access: http: //theconversation.com/qanda-why-credit-ratingagencies-matter-for-developing-countries-

51964. - Title from the screen.

17. Fitch ratings [Electronic resource]. - Mode of access : https://www.fitchratings.com/. - Title from the screen.

18. Moody`s credit rating [Electronic resource]. - Mode of access : https://www.moodys.com/. - Title from the screen.

19. S\&P Global ratings [Electronic resource]. - Mode of access: https://www.standardandpoors.com. - Title from the screen.

20. Офіційний сайт Світового Банку [Електронний ресурс]. - Режим доступу : http://databank.worldbank.org/. - Назва 3 екрана.

21. National investment promotion and Facilitation Agency [Electronic resource]. Mode https://www.investindia.gov.in/why-india. Title from the screen.

22. Make in India [Electronic resource]. - Mode of access: http://www.makeinindia.com/home. - Title from the screen.

23. Government of India [Electronic resource]. - Mode of access: https://community.data.gov.in/total-foreigndirect-investment-equity-inflows-from-200001-to-2016-17/. - Title from the screen.

24. Ernst\&Young

[Electronic resource]. - Mode of access : https://www.ey.com/in/en/newsroom/news- releases/ey-will-it-make-india-an-attractiveinvestment-destination. - Title from the screen.

25. Department of Foreing Affairs and Trade [Electronic resource]. - Mode of access: https://dfat.gov.au/geo/india /ies/overview.html. - Title from the screen.

\section{REFERENCES}

1. Galishcheva N. V. (2012) Chem Indiya privlekaet inostrannykh investorov [How India attracts foreign investors]. Asia and Africa today. No. 1, pp. 29-35.

2. Kandalintsev V. G. Indiya: investitsionnyy klimat i pritok PII [India: investment climate and FDI inflows]. Available at: https://cyberleninka.ru/ /n/indiyainvestitsionnyy-klimat-i-pritok-pii

3. Revina E. Ya. (2009) Pryamye inostrannye investitsii $\mathrm{v}$ ekonomike Indii [Foreign Direct Investment in the Indian Economy]. Moscow University Bulletin. No. 3, pp. 39-47.

4. Pami Dua, Reetika Garg. (2015) Macroeconomic Determinants of Foreign Direct Investment: Evidence from India. The Journal of Developing Areas, Vol. 49(1). - pp. 133-155. Project

MUSE,

doi:10.1353/jda.2015.0025. - Title from the screen.

5. Aggarwal Vipin Kumar, Nayyar Rishika. (2017) Financial sector development, Foreing direct investment and economic growth in India: an empirical analysis. Asian Journal of Research in Banking and Finance, Vol. 7. - No. 6. - pp. 179-196. Available at: http://www.indianjournals.com/ijor.aspx?target $=$ ijor:ajrbf \&volume $=7 \quad$ \&issue $=6 \&$ article $=014$. - Title from the screen.

6. Venkatesan R. (2018) Role of Foreign Direct Investment in India. International Journal of Advanced Scientific Research \& Development (IJASRD), Vol. 05. No. 03, pp. 411 - 415. Available at: https://www.ijasrd.org/wpcontent/uploads/2018/10/Role-of-ForeignDirect-Investment-in-India.pdf. - Title from the screen. 
7. Department of Industrial Policy \& Promotion. Available at: https://dipp.gov.in/foreign-directinvestment/foreign-direct-investment-policy

8. CEIC Data. Available https://www.ceicdata.com/en/indicator/india/gd p-per-capita.

9. Index Mundi Available at: https://www.indexmundi.com/g/g.aspx?c=in

10. Dokladi o mirovikh investitsiyakh

[World Investment Report]. : UNCTAD Conference. Available at https://unctad.org/en/Pages/publications.aspx.

11. Galishcheva N.V. (2017) Globalizatsiya indiyskoy ekonomiki: tendentsii i perspektivy [The globalization of the Indian economy: trends and prospects]. Bulletin of MGIMO-University. Vol. 2(53), pp. 71-89.

12. World Economic Forum. Available at: $\quad$ https://www.weforum.org/search query $=$ Global + Competitiveness + Report

13. The Global Competitiveness Report 2017-2018. Available at: htps://espas.secure.europarl.europa.eu/orbis/site s/default/files/generated/document/en/TheGlob alCompetitivenessReport2017-2018.pdf.

14. Doing Business: assessment of the quality and effectiveness of regulation. Available at: http://russian.doingbusiness. org/ru/reports/global-reports/doing-business2019.

15. Index of Economic Freedom [Electronic resource]. - Mode of access:
http://www.heritage.org/index/country/India. Title from the screen.

16. The Conversation. Why credit rating agencies matter for developing countries Available at: http: //theconversation.com/qanda-why-credit-ratingagencies-matter-for-developing-countries51964.

17. Fitch ratings Available at: https://www.fitchratings.com/.

18. Moody`s credit rating Available at: https://www.moodys.com/.

19. S\&P Global ratings Available at: https://www.standardandpoors.com.

20. World Bank Official Website. Available at: http://databank. worldbank.org/.

21. National investment promotion and Facilitation Agency. Available at: https://www.investindia.gov.in/why-india.

22. Make in India Available at: http://www.makeinindia.com/home.

23. Government of India. Available at: https://community.data.gov.in/total-foreigndirect-investment-equity-inflows-from-200001-to-2016-17/.

24. Ernst\&Young. Available at: https://www.ey.com/in/en/newsroom/newsreleases/ey-will-it-make-india-an-attractiveinvestment-destination

25. Department of Foreing Affairs and Trade. Available at: https://dfat.gov.au/geo /india/ies/overview.html.

\title{
ACTIVITY-HOLISTIC VIEW ON ESSENTIAL CONTENT OF MODERN FINANCE
}

\author{
Serikov A.V., PhD of Phys.-Math. Sc., Professor, Full Professor \\ (Kharkiv National University of Civil Engineering and Architecture)
}

Based on the activity-holistic analysis of the problem, the paper shows that finance is a component of the life activity of economic entities of all levels (individual, family, firm, community, state), within which they perform high-performance economic activity, while carrying out processes of targeted movement of the exchange value of their monetary capital 